\title{
COMMENTS
}

\section{LIABUITY FOR VIOLATION OF STATE LABOR INJUNCTIONS WHERE POWER TO ENJOIN IS SUBSEQUENTLY HELD TO HAVE BEEN PREEMPTED}

Twice during the 1959 term the Supreme Court declined to grant certiorari for the consideration of an issue which may have serious implications for federal preemption in labor disputes. ${ }^{1}$ That issue is whether a union which has violated a temporary state injunction prior to a determination that power to issue it has been preempted by Congress is immune to contempt proceedings after such a determination has been made. ${ }^{2}$

The traditional equity rule is that although a merely erroneous order must be obeyed, an order issued by a court which lacked jurisdiction over the subject matter of the dispute is void and may be disobeyed with impunity. ${ }^{3}$ Since the Supreme Court has cast its preemption doctrine in terms of "a withdrawal of jurisdiction" from state courts, the traditional rule implies that those temporary injunctions of state courts which extend to federally-preempted matters may be disobeyed with impunity.

The Supreme Court, however, in United States v. United Mineworkers, ${ }^{4}$ departed from the traditional rule that an injunction issued without jurisdiction is void. The rule of that case appears to be that a court presented with a "non-

1 McCrary v. Aladdin Radio Indus., Inc., 361 U.S. 865 (1959), denying cert. in Aladdin Indus., Inc. v. Associated Transp., Inc., 323 S.W.2d 222 (Tenn. App. 1958); Bogle v. Jakes Foundry Co., 362 U.S. 401 (1960), refusing to extend certiorari to the contempt aspect of Jakes Foundry Co. v. Tennessee-Carolina Transp., Inc., 329 S.W. 2d 364 (Tenn. App. 1959).

2 The question has come up for decision in a number of recent cases in the state courts. See Ex parte Dilley, Zea \& Cooper, 334 S.W.3d 425 (Tex. 1960); Angle v. Owsley, 332 S.W.2d 457 (Mo. 1959); Robinson v. Hoover Motor Express Co., 44 L.R.R.M. 2744 (Tenn. App. 1959); Jakes Foundry Co. v. Tennessee-Carolina Transp., Inc., supra note 1; Town and Country Motors v. Local 328, 355 Mich. 26, 94 N.W.2d 442 (1959); Aladdin Indus. v. Associated Transp., Inc., supra note 1; Ex parte Twedell, 158 Tex. 214, 309 S.W.2d 834 (1958).

${ }^{3}$ Ex parte Dilley, Zea \& Cooper, 334 S.W.2d 425 (Tex. 1960); Ex parte Twedell, 309 S.W.2d 834 (Tex. 1958); Angle v. Owlsey, 332 S.W.2d 457 (Kansas City Ct. App. 1959); I JoxCE, INJUNCTIONS § 246 (1909); II HIGH, INJUNCTIONS § 1425 (1905); Brown, JURISDICTION \$ 120 (1891); 12 AM. JUR. Contempt $\$ 26$ (1938); 43 C.J.S. Injunctions $\$ 258$ (1945); cases collected in Annot., 12 A.L.R.2d 1059 (1950).

4330 U.S. 258 (1947). The Court, with two justices dissenting, upheld criminal contempt convictions against John $\mathrm{L}$. Lewis and the United Mineworkers for disobeying a temporary restraining order of a federal district court. The order had been issued to restrain a threatened strike, while the court decided inter alia whether the Norris-LaGuardia Act prohibited injunctive relief at the instance of the federal government, which at the time was running the coal mines, in the same way that the act prevented private employers from obtaining such relief in their disputes with employees. 
frivolous" or reasonable claim of jurisdiction has the power to undertake an inquiry into the merits of that claim, ${ }^{5}$ and any orders issued to preserve the status quo pending that investigation must be obeyed irrespective of the outcome of the inquiry into jurisdiction. ${ }^{6}$ If the Mineworkers doctrine were applied to state labor injunctions, it would appear that where a state court's claim of jurisdiction was not "frivolous" the court would have "jurisdiction to determine its jurisdiction" and its temporary injunctions ${ }^{7}$ would be enforceable although the issuing court was ultimately found to be without jurisdiction over the merits.

Under the preemption doctrine, in its present stage of development, there appear to be several situations in which a state court might be faced with what it considers a "non-frivolous claim of jurisdiction" in a suit for a labor injunction. Included among the possible bases of such claims are the following. First, that the labor activity sought to be enjoined involves actual or threatened violence. ${ }^{8}$ Second, that there is insufficient effect on interstate commerce to meet the NLRB's jurisdictional standards. ${ }^{9}$ Third, that the dispute is primarily con-

5 "To be sure, an obvious limitation upon a court cannot be circumvented by a frivolous inquiry into the existence of a power that has unquestionably been withheld. ... In such a case a judge would not be acting as a court. He would be a pretender to, not a wielder of, judicial power." 330 U.S. at 310 (concurring opinion, Frankfurter, J.).

- This theory will hereinafter be referred to as the Mineworkers doctrine. It was the alternate ground upon which three members of the Court (Vinson, C. J., Burton, J., Reed, J.) rested affirmance of the contempt convictions in Mineworkers and was the sole ground for two other Justices who supported the convictions. (Frankfurter, J., Jackson, J.). Black, J. and Douglas, J. did not reach this issue in their opinion. Murphy, J. and Rutledge, $J$., in dissenting, voiced strong opposition to this theory of judicial power. For a comprehensive discussion of this aspect of the Mineworkers case, as well as its historical antecedents, see Cox, The Void Order and the Duty to Obey, 16 U. Crr.L. REv. 86 (1948), and the cases and articles cited therein. For early discussion of the theory propounded in the Mineworkers decision see Ex parle Wimberly, 57 Miss. 437 (1879); and VANFLEET, ColLATERAI ATTACK $\$ \S 1,66$ (1892), in which the author argues for the broader proposition that no order, temporary or final, should be subject to collateral attack in any proceeding if there is even a "colorable" claim of jurisdiction in the court which issued the order.

7 This comment is limited to a consideration of the enforceability of temporary injunctions as opposed to permanent injunctions. Neither the Mineworkers decision nor the authorities relied on by the Supreme Court in that opinion were concerned with the duty to obey a permanent injunction. There seems to be no rational reason for enforcing more vigorously a temporary injunction granted before a full consideration of the jurisdiction issue than $a$ permanent injunction granted only after a full hearing. Nevertheless, the decisions and language of the courts applying the Mineworkers doctrine have been restricted, on the whole, to temporary injunctions and the traditional equity rule has gone virtually unchallenged in the area of permanent injunctions. See Annot., 12 A.L.R.2d 1059, 1078-79 (1950). But see Luster v. Auxier, 285 S.E.2d 900 (Ky. 1955), which relied on Mineworkers to support a final order.

8 For a discussion of this exception to preemption see Meltzer, The Supreme Court, Congress, and State Iurisdiction Ozer Labor Relations (pt. 1), 59 Colos. L. Rev. 6, 26-36 (1959). The state courts retain power to issue injunctions in labor disputes where such action is allegedly necessary to stop current violence or to prevent future violence.

- Under the Landrum-Grifin amendment to the IMRÁ, state courts have jurisdiction over disputes involving business concerns which transact less business in interstate commerce than certain "dollar amounts" established by the NLRB. 61 Stat. 151 (1947), as amended, 29 
cerned with the interpretation of the collective bargaining contract itself, rather than the means of reaching that agreement..$^{10}$ Fourth, that the activity cannot reasonably be considered either protected or prohibited by the LMRA."1

This comment will first explore the considerations relevant to a choice between applying the traditional rule or the Mineworkers solution to employees and unions who disobey state labor injunctions issued without jurisdiction although pursuant to such a "non-frivolous claim of jurisdiction." It will then consider whether the choice between these two courses of action is strictly a matter of state law or if it is properly a question of federal law. Two additional solutions which might be suggested in this situation will also be set forth and their inadequacies discussed.

Because the Supreme Court has not yet consented to decide any of these issues, it is necessary to consult opinions in the state courts for judicial discussion of whether the Mineworkers doctrine or the traditional equity rule should be applied to state labor injunctions. The Tennessee Court of Appeals, in a series of recent decisions, ${ }^{12}$ has become the first state court to rely on the Mineworkers theory to uphold contempt convictions for the violation of state labor injunctions issued in the preempted area. In Aladdin Indus., Inc. v. Associated Transp., Inc., ${ }^{13}$ a manufacturer requested an injunction to compel fourteen common carriers to resume deliveries to it. The complaint recited that the deliveries had been curtailed because the carriers' employees had refused to cross a picket line established by a union striking against an affliate of the manufacturer housed on the same premises. The trial court granted a temporary injunction which ran against the carriers, "their officers, agents and employees." This injunction was obeyed for approximately three months. Then the union employees of the carriers once more refused to cross the picket line. In the ensuing contempt proceeding, thirteen of the drivers and their union were adjudged

U.S.C.A. $\$ 164$ (c) (Supp. 1959). Questions are likely to arise over what portion of the business conducted by an enterprise is to be considered interstate commerce, the actual amounts attributable to a given period, and the effect on pending litigation of a change in the amount of interstate commerce engaged in by the employer.

${ }^{10}$ For a discussion of this exception to preemption, see Meltzer, supra note 8, at 276-81. The article points out inter alia the difficulties which may accompany a decision as to whether a given dispute is merely one over contract interpretation or whether it involves prohibited or protected labor activity.

"1 See 61 Stat. 140 (1947), as amended, 29 U.S.C. $\$ \$ 157-58$ (1958). The scope of this exception has been curtailed by the Supreme Court's decision in San Diego Building Trades Council. v. Garmon, 359 (1959). It was held in that case that if the labor activity in dispute was arguably protected or prohibited by the LMRA, the NLRB had exclusive primary jurisdiction to decide whether state or federal power should attach. However, the Court in Garmon left open the question of whether the state courts are free to enjoin activity expressly held neither prohibited nor protected by the IMRA.

12 Jakes Foundry Co. v. Tennessee-Carolina Transp., Inc., 329 S.W.2d 364 (Tenn. App. 1959); Robinson v. Hoover Motor Express Co., 44 L.R.R.M. 2744 (Tenn. App. 1959); Aladdin Indus., Inc. v. Associated Transp., Inc., 323 S.W.2d 222 (Tenn. App. 1958).

${ }^{13} 298$ S.W.2d 770 (Tenn. App. 1956). 
guilty of contempt. The defense that the state court's power was preempted by the LMRA was met by the contention that such labor activity was neither prohibited nor protected by the federal act, and thus the state court was free to regulate it. This theory of jurisdiction was rejected by the United States Supreme Court in a per curiam decision ${ }^{14}$ which vacated and remanded the contempt decrees.

On remand, the Tennessee court sustained the contempt decree on a new theory of jurisdiction. ${ }^{15}$ It declared that the facts alleged in the complaint created a substantial doubt as to whether the court had been without power, ${ }^{16}$

${ }^{14} \mathrm{McCrary}$ v. Aladdin Radio Indust., Inc., 355 U.S. 8 (1958). The Tennessee Court of Appeals was directed to reconsider the Aladdin case in the light of Weber v. Anheuser-Busch, 348 U.S. 468 (1955) and Union v. Kerrigan Iron Works, Inc., 353 U.S. 968 (1957). For a critical discussion of this per curiam disposition of the Aladdin case, see Comment, Per Curiam Decisions of the Supreme Court: 1957 Term, 26 U.CHr.L.Rev. 279, 288-303 (1958).

${ }^{15}$ Aladdin Indus., Inc. v. Associated Transp., Inc., 323 S.W.2d 222 (Tenn. App. 1958).

${ }^{16}$ The Tennessee Court presented two reasons for believing it had a "non-frivolous" claim of jurisdiction over the Aladdin controversy. First, the court urged that the state court could assume jurisdiction because it was arguable that the union activity involved was neither protected nor prohibited by the LMRA. If a state court were to attempt to justify an injunction on such grounds now, this would probably not constitute a substantial claim of jurisdiction inasmuch as the Supreme Court has announced that the NLRB, not the state courts, has exclusive primary jurisdiction to determine whether activity is protected or prohibited by the LMRA. San Diego Building Trades Council. v. Garmon, 359 U.S. 236 (1959). At the time the Tennessee trial court entered its injunction, however, Garmon had not been decided, and it was far from clear whether the exclusive primary jurisdiction of the NLRB extended to a case such as Aladdin in which no violation of a specific section of the LMRA was alleged by the employer seeking the injunction. The strongest language of the Court prior to Garmon was contained in the Weber case: "[W] here the moving party itself alleges unfair labor practices, where the facts reasonably bring the controversy within the sections prohibiting these practices, and where the conduct, if not prohibited by the federal Act, may be reasonably deemed to come within the protection afforded by the Act, the state court must decline jurisdiction in deference to the tribunal which Congress has selected for determining such issues in the first instance." Weber v. Anheuser-Busch, 348 U.S. 468, 481 (1955).

The second contention made by the Tennessee court was that, even assuming that the state court would have clearly lacked jurisdiction because of federal preemption to enjoin the union and its members, Aladdin did not concern an injunction against a union or its members. It was an injunction against the carriers-an order that the court clearly did have jurisdiction to issue. At the time the state trial court assumed jurisdiction over the case there was no possibility of federal jurisdiction because the complaint was not directed against the union or union members as such but solely against the carriers. It was urged in the Aladdim opinion that the jurisdiction of a court must be decided on the basis of the pleadings at the commencement of the suit and that subsequent factual revelations cannot dislodge that jurisdiction. But that does not dispose of the question whether an injunction issued on the basis of such jurisdiction can be enforced against parties who, if included in the original pleadings in the capacity (in this case as union members) in which they are charged with contempt, would have ousted the court of jurisdiction to issue the order in the first instance. In other words, it would appear improper for the Tennessee Court to issue an order against the carriers, and incidentally their employees qua employees (the Court having jurisdiction only over the carriers) and then to enforce it against the union and its members qua members (a group against which the state court by hypothesis lacked power to issue such an injunction). To ratify such a line of reasoning would enable plaintiffs and courts to accomplish by indirection what they were prohibited from doing directly, and thus to exercise power over parties and subject matter beyond the boundaries of their jurisdiction. 
and that pending a resolution of that question, the state trial court had jurisdiction to issue a temporary injunction which the employees were bound to obey. The defendant employees again petitioned the Supreme Court for a writ of certiorari. This time the Court denied the petition ${ }^{17}$ thereby passing up its first opportunity ${ }^{18}$ of the 1959 term to resolve the issue of whether state labor injunctions are to be enforceable irrespective of any subsequent finding on the jurisdiction of the issuing court.

To support its application of the Mineworkers doctrine the Tennessee court referred to several state decisions allegedly demonstrating that this was the law in Tennessee ${ }^{19}$ and then cited the series of federal decisions ${ }^{20}$ culminating in Mineworkers. Of all the cases mentioned by the Tennessee Court only the Mineworkers decision itself fully discusses the rationale underlying this doctrine. In that decision, the fundamental policy was articulated in terms of preserving respect for courts and encouraging obedience to court orders. It was urged that permitting disobedience under any circumstances to any court order-including one issued pending a determination of the court's power to act-would tend to incite disrespect and disobedience toward all judicial orders. ${ }^{21}$

In striking contrast to the position of the Tennessee Court of Appeals and the policy expressed in Minezvorkers, is the decision of the Michigan Supreme

${ }^{17}$ McCrary v. Aladdin Radio Indus., Inc., 361 U.S. 865 (1959).

${ }^{18}$ The second opportunity was in Bogle v. Jakes Foundry, 362 U.S. 401 (1960).

19 It is questionable whether these cases actually justify a finding that the Mineworkers doctrine was ever a part of Tennessee law. In Weidner v. Friedman, 126 Tenn. 677, 151 S.W. 56 (1912), the Tennessee Supreme Court reversed an injunction against some "disorderly houses" but upheld contempt convictions against the owners for their disobedience while the case was pending on appeal. However, it was not held that the injunction was void for lack of jurisdiction in the issuing court but merely that it was an improvident exercise of such jurisdiction. The Tennessee Supreme Court in Weidner felt that the Chancellor should have exercised forbearance in the exercise of his equity powers. Upholding contempt convictions for disobedience to an improvidently issued injunction is clearly consistent with the traditional equity rule: See 43 C.J.S. Injunctions $\$ 258$ (1945): State v. Ragghianti, 129 Tenn. 560,167 S.W. 689 (1914) is distinguishable on the grounds that the lack of notice was held not to go to the jurisdiction of the court: In Howell v. Thompson, 130 Tenn. 311, 170 S.W. 253 (1914), it was held that supersedeas would not be granted to vacate an injunction issued by a court lacking jurisdiction of the subject matter. However, it was also stated by the court in that case that supersedeas might be granted to prevent enforcement of such an injunction.

- In Churchwell v. Callens, 36 Tenn. App. 119, 252 S.W.2d 131 (1952), the court clearly had jurisdiction in the case. The only reference to the contempt problem was a dictum which adhered to the classical equity rule, making no mention of the Mineworkers doctrine. Id. at 133.

${ }^{20}$ United States v. Shipp, 203 U.S. 563 (1906); Carter v. United States, 135 F.2d 855 (5th Cir. 1943). Cf. Howat v. State of Kansas, 258 U.S. 181 (1922).

2I Mr. Justice Frankfurter wrote an eloquent statement of this policy in his concurring opinion in Mineworkers: "No one ... can be'judge in his own case. That is what courts are for. And no type of controversy is more peculiarly fit for judicial determination than a controversy that calls into question the power of a court to decide.

"If one man can be allowed to determine for himself what is law every man can. That means first chaos, then tyranny." 330 U.S. at 308-09, 312. 
Court in Town \& Country Motors v. Local Union 328.22 The situation in Town \& Country Motors involved at least as substantial a claim of jurisdiction as did that in the Aladdin case. Prior to the Supreme Court's decision in Guss v. Utah Labor Relations Board ${ }^{23}$ a Michigan trial court had entered a temporary restraining order against organizational picketing of the plaintiff's automobile agency. It took this action on the grounds that the enterprise did not meet the NLRB's jurisdictional standards and consequently that the latter would not take cognizance of the dispute. At that time, it was unclear whether failure to meet NLRB standards placed the dispute within the purview of the state courts. ${ }^{24}$ Shortly after the restraining order was issued the union disobeyed it. A contempt action was then initiated against the union. Not until several months later did the Gruss decision resolve the issue of state authority to act in the noman's land by holding that state courts were precluded from entering this area. ${ }^{25}$

These facts presented a strong basis for the contention that, irrespective of the validity of the underlying restraining order, the union's disobedience should have been punished. When issued and ignored by the union, the order was consistent with many state decisions ${ }^{26}$ and with the official position of the NLRB. ${ }^{27}$ Clearly, it presented a "non-frivolous" claim of jurisdiction. In justifying its refusal to allow the enforcement of the restraining order, ${ }^{28}$ the Michigan Supreme Court discussed the potential dangers which, in its opinion, made mandatory a reversal of any contempt conviction resulting from disobedience of a state injunction in the preempted area.

The court first pointed to the history of the employer-initiated "temporary" labor injunction and its manifold abuses. ${ }^{29} \mathrm{~A}$ temporary injunction, allegedly

2 355 Mich. 26, 94 N.W. 2d 442 (1959).

${ }^{23} 353$ U.S. 1 (1957).

${ }^{23}$ Among those cases which had taken the same position as the Michigan court were: Garmon v. San Diego Building Trades Council, 45 Cal.2d 657, 291 P.2d 1 (1955); Building Trades Council v. Bonito, 71 Nev. 84, 280 P.2d 295 (1955); Hammer v. Local 211, United Textile Workers, 34 N.J.Sup. 34, 111 A.2d 308 (1954); Dallas General Drivers v. Jax Beer Co., 276 S.W.2d 384 (Tex. Civ. App. 1955).

${ }^{25}$ Guss v. Utah Labor Relations Board, 353 U.S. 1 (1957). Accord: Amalgamated Meat Cutters v. Fairlawn Meats, Inc., 353 U.S. 20 (1957); San Diego Building Trades Council v. Garmon, 353 U.S. 26 (1957).

${ }^{26}$ See note 24 sicpra.

${ }^{27}$ Brief for NLRB as Amicus Curiae, Guss v. Utah Labor Relations Board, 353 U.S. 1. This position was noted in the dissenting opinion in Guss: "The Court's interpretation of the proviso is contrary to the established practice of the states and of the National Board, as well as to the considered position taken by the Board as amicus curiae." 353 U.S. at 18.

${ }^{28}$ The Michigan court reversed the restraining order and refused to "remit to the (trial) court the fruitless task of ascertaining whether or not certain acts of the defendants constituted a 'contempt' of the void order." 355 Mich. at 54-55, 94 N.W.2d at 457.

${ }^{29}$ A dramatic example of how "non-temporary" such "temporary" injunctions can be is furnished by Angle v. Owsley, 332 S.W.2d 457 (Kan. City. Ct. App. 1959). In that case a union leader was cited for contempt in 1959 for disobeying a "temporary" injunction issued over eight years previously in 1951 . 
issued to maintain the status quo, often had the effect of breaking a strike..$^{30}$ The court found in the legislative history of the federal labor acts a clear purpose to bar such employer-initiated injunctions from the area preempted by the national labor policy. ${ }^{31}$ The Michigan court then argued that this congressional purpose would be thwarted by the encroachment of employer-initiated state labor injunctions on the federal area if disobedience of these injunctions were punished irrespective of lack of state jurisdiction. ${ }^{32}$ National uniformity in the field of labor policy would also suffer because of differences among the state courts as to the outer limits of the federally preempted area, and in their willingness to act in disputes potentially infringing on that area. ${ }^{33}$

The fears expressed by the Michigan court concerning the effective application of the national labor policy if the Mineworkers theory were activated in the area of state labor injunctions would appear to be justified. Although the Norris-LaGuardia Act has virtually eliminated the employer-initiated temporary labor injunction from the federal courts, ${ }^{34}$ the threat of state court injunctions remains. ${ }^{35}$ Often granted without a hearing, on dubious allegations of fact and law, such temporary injunctions are immune from direct attack in the federal courts. ${ }^{36}$ Since they are interlocutory orders, in some states they are not appealable even in the state courts. ${ }^{37}$

The effectiveness of the Supreme Court's preemption doctrine in excluding such state interferences from certain areas of labor relations would probably be

so "The (temporary labor) injunction cannot preserve the so-called status quo; the situation cannot remain in equilibrium awaiting judgment upon full knowledge. The suspension of activities affects only the strikers; the employer resumes his efforts to defeat the strike, and resumes them free from interdicted interferences. Moreover, the suspension of strike activities, even temporarily, may defeat the strike for practical purposes and foredoom its resumption, even if the injunction is later lifted." Frankfurter \& Greene, The Labor Injunction 201 (1930), quoted with approval, 355 Mich. at 50-51, 94 N.W.2d at 454-55.

${ }^{31} 355$ Mich. at 53-54, 94 N.W.2d at 455-56. "The legislative history of the amendment of the act in 1947 makes clear that the Congress continued to reject the scheme of relief at the instance of employers though it imposed new limitations on the activities of unions." 355 Mich. at 52,94 N.W.2d at 455 .

32355 Mich. at 52, 94 N.W.2d at 455.

${ }^{33} 355$ Mich. at 54,94 N.W.2d at 456.

${ }^{34}$ "While there have been injunctions in the Federal courts against labor unions, the number of such orders has greatly decreased since enactment of the Norris-La Guardia Act. By the end of $1931 \ldots$ at least 508 injunctions had been issued in labor-management disputes by Federal courts. ... This number is to be contrasted with the 66 Federal injunctions discovered ... since January 1, 1933." Staff of Subcomar. on Labor-Management Relations, Senate Consr. on Labor and PUBlic Welfare, Report on State Court Injunctions, S. Doc. No. 7, 81st Cong., 2d Sess. 4 (1951).

35 "There has occurred a far lesser decrease in the number of injunctions issued in the State courts against unions on the suit of employers than in the Federal Courts." Id. at 5.

${ }^{35}$ Amalgamated Clothing Workers v. Richman Bros. Co., 348 U.S. 511 (1955). For further discussion of this matter, see notes 58-65 infra and accompanying text.

${ }^{37}$ E.g., Robinson v. Hoover Motor Express Co., 44 L.R.R.M. 2744 (Tenn. App. 1959). 
greatly diminished by the adoption of a policy which required obedience to all injunctions issued by state courts having a colorable claim of jurisdiction. ${ }^{38}$ First, employers might be encouraged to seek more injunctions in the state courts by framing complaints presenting some claim of jurisdiction, possibly omitting any facts which would automatically oust the state court from jurisdiction. Secondly, some state courts, which have often shown themselves to be sympathetic to the granting of temporary injunctions whether they were firmly convinced of their own jurisdiction or not, ${ }^{39}$ might look favorably on these complaints and issue a greater number of such injunctions. The courts would know that their orders must be obeyed even though they actually lacked power to determine the issue on the merits. Therefore, it might be reasonable to anticipate a significant increase in the number of employer-initiated state injunctions. ${ }^{40}$ Similarly, the probability that employees would obey such injunctions would be greatly increased since the employees would realize that they would be guilty of contempt even if it were later concluded that the state court lacked power to determine the dispute on the merits. The interference of state courts, and thus the imposition of state policies in the province of federal labor regulation, would be limited only by the ingenuity that employers could display in contriving new means of presenting a "non-frivolous" claim of jurisdiction in their allegations. ${ }^{41}$

Consequently, it would appear that the integrity of federal labor policy may be seriously jeopardized by allowing state courts to invoke the Mineworkers theory in support of their temporary injunctions in labor disputes, and that a rejection of the Mineworkers doctrine in this type of dispute would be justified. But while the federal interest in effectuating its labor policy must be recognized, it cannot be denied that the states also have a considerable interest in maintain-

${ }^{38}$ "'The procedure urged would, as a practical matter, mean the end of the federal preemption of the field and the utter nullification of clear congressional intent that there be national uniformity of treatment of this complex social and economic problem." 355 Mich. at 54, 94 N.W.2d at 456.

${ }^{39}$ E.g., "If we rule against jurisdiction and we are wrong in so ruling, the unsuccessful litigant may well be irreparably harmed. We are of the mind that any doubt should be resolved in favor of jurisdiction, leaving to the Supreme Court to finally resolve the matter." Pleasant Valley Packing Co. v. Talarico, 5 N.Y. 2d $40,47,177$ N.Y.S.2d 473, 478 (1958).

${ }^{10}$ For an excellent discussion of the many factors other than enforceability which influence the number of injunctions sought and issued, see Report on State Court Injunctions, supra note 34 at 4-12.

11 Some indication of the readiness of employers in certain regions of the country to avail themselves of any opportunity to gain an injunction is supplied by the two Tennessee cases since Aladdin which were brought on an identical claim of jurisdiction, with a complaint directed, as in Aladdin, against the carriers rather than the union or the employees. Jakes Foundry Co. v. Tennessee-Carolina Transp., Inc., 329 S.W,2d 364 (Tenn. App. 1959), Robinson v. Hoover Motor Express Co., 44 I.R.R.M. 2744 (Tenn. App. 1959). For a list of additional cases recently brought on a similar claim of jurisdiction in the trial courts of Tennessee, see Petition for Writ of Certiorari, Brief for Petitioner, p. 18 n.12, McCrary v. Aladdin Indus., 361 U.S. 865 (1959). 
ing respect for their courts. A balancing of these competing federal and state interests would have to be undertaken to properly decide between the alternatives of invoking the Mineworkers doctrine or permitting disobedience when the state courts lack jurisdiction.

The foregoing discussion has been devoted to the question of whether disobedience should be punished. The next problem which must be confronted is whether state or federal law is to be determinative of this issue. It was argued by the employer's counsel in the Aladdin case ${ }^{42}$ that the enforceability of state court injunctions, whether issued with or without jurisdiction, is solely a matter of state law..$^{43}$ Under this theory, if state law follows the Mineworkers doctrine, the federal question of whether power to issue the underlying injunction has been preempted is never reached in the contempt case because the contempt order is enforceable even if power to issue the injunction has been preempted. If this argument were accepted, the Supreme Court might be precluded from reviewing the state contempt conviction, inasmuch as that conviction would rest on adequate non-federal grounds. ${ }^{44}$ This was the argument advanced by the employer's counsel in urging that the Supreme Court should deny certiorari in Aladdin.45

The foregoing argument presupposes that power to issue the contempt order itself is not, or at least should not, be subject to preemption. Some of the possible obstacles to the effective operation of the federal labor program, which such contempt orders create, have already been discussed. ${ }^{46}$ An additional obstacle would be added if each state were allowed to apply its own law concerning the enforceability of injunctions issued without jurisdiction. It would tend to sabotage the national uniformity which the federal labor relations program is designed to promote. Some states would apply the traditional equity rule and not

${ }^{42}$ Petition for Writ of Certiorari, Brief for Respondents in Opposition, p. 9, McCrary v. Aladdin Indus., 361 U.S. 865 (1959).

${ }^{13}$ Assuming that the question of whether the Mineworkers doctrine is to be applied at all to state court labor injunctions is a state question, certain subsidiary problems might still arise as to whether there are any federal limitations on state application of that doctrine in this area. (1) If the state law so provided, could a state court support a contempt conviction by invoking the Mineworkers doctrine even though it did not have a "non-frivolous" claim of jurisdiction? (2) Even if the state law required that its courts have a "non-frivolous" claim of jurisdiction before invoking that state's version of the Mineworkers doctrine, would the "nonfrivolous" nature of that claim be measured against a state or federal standard of "frivolity"? (3) Would the state court ruling that it had a "non-frivolous" claim of jurisdiction be final, or would that aspect of the contempt conviction at least, be reviewable by the Supreme Court.

44 "[W] $[$ here the judgment of a state court rests upon two grounds, one of which is federal and the other non-federal in character, our jurisdiction fails if the non-federal ground is independent of the federal ground and adequate to support the judgment." Fox Film Corp. v. Muller, 296 U.S. 207, 210 (1935). Accord: McCoy v. Shaw, 277 U.S. 302 (1928); Petrie v. Nampa \& Meridian Irrigation Dist., 248 U.S. 154 (1918); Klinger v. Missouri, 80 U.S. (13 Wall.) 257 (1871).

15 "The decision of the Tennessee Court of Appeals rests solidly on the adequate non-federal ground. ... Accordingly the petition for certiorari should be denied. . ." Petition for Writ of Certiorari, Brief for Respondents in Opposition, at 9.

${ }^{16}$ See notes 34-41 supro and accompanying text. 
punish disobedience of preempted injunctions; others would invoke the Mineworkers doctrine and punish similar acts which violated similar injunctions; and even among those states which invoked the Mineworkers doctrine there would be different standards for determining what constituted a "non-frivolous claim of jurisdiction." Consequently any uniformity achieved in excluding state injunctions from certain areas would be subverted by a lack of uniformity in the fate met by contempt decrees in those areas.

Because of this potential impact on the federal labor relations program, it would seem that the issue of the enforceability of preempted state labor injunctions is invested with considerable federal interest. So long as the state order, whether it is an injunction or a contempt order, could potentially interfere with the objectives of the federal labor program it would appear susceptible to preemption $^{47}$ and thereby to review in the federal courts. ${ }^{48}$ But whether these contempt orders should be preempted hinges again on the balancing of this federal interest against the state interest in enforcing their labor injunctions irrespective of jurisdiction. .9 $^{9}$

If the entire area were held to be preempted by the federal government, it would then be the federal law concerning the enforcement of temporary injunctions which would control the resolution of the contempt issue. In this connection it is well to remember that the Mineworkers case involved only an interpretation of the equity powers of the federal district courts. A conflict between federal and state policies was not in issue. Therefore, Minezvorkers does not necessarily imply that a state court can impose an absolute duty to obey its orders when to do so has serious implications for a program of the federal government. ${ }^{50}$ If federal law provides the relevant standard, it would appear

47 This was the view of the Michigan Supreme Court in Town and Country Motors: "Where ... the National Labor Relations Act pre-empts the field and exclusive jurisdiction is vested in the NLRB, both authority to enjoin within the pre-empted area and to punish for contempt of the null injunction are denied the State by the Federal act." 355 Mich. at 55, 94 N.W.2d at 457 (Emphasis supplied).

18 Federal preemption of state court labor injunctions would have little meaning if it could be circumvented by the enforcement of preempted injunctions merely because an adequate and independent state ground existed for such enforcement. "Controlling and therefore superseding federal power cannot be curtailed by the State even though the ground of intervention be different than that on which the federal supremacy has been exercised." Weber v. AnheuserBusch, Inc., 348 U.S. 468, 480 (1955).

49 This same issue could also be framed in the fictive language of "congressional intent." The issue would then be whether Congress in enacting its labor legislation "intended" to nullify contempt orders issued in labor disputes withdrawn from state power in the same way that it has nullified injunctions issued in such disputes.

${ }^{50}$ In Mineworkers, the issue was whether the federal courts had jurisdiction over the dispute or if they were prohibited from acting by the Norris-LaGuardia Act. The case did not involve a question of which of two court systems had jurisdiction to enjoin but rather whether any court had such power. In a similar state injunction case, the Minnesota Supreme Court noted the absence of any issue of federalism. "In that [Reid v. Independent Union of All Workers, 200 Minn. 599, 275 N.W.300 (1937)] case there was no conflict between state and federal courts. ... Much the same was true in the case of United States v. United Mineworkers." Norris Grain Co. v. Nordaas, 232 Minn. 91, 98, 46 N.W.2d 94, 99 (1950). 
that the Supreme Court remains free, despite its Minerworkers decision, to adopt the traditional equity rule as the federal law to be applied to contempt orders arising out of state labor injunctions.

Before concluding that the state courts or the Supreme Court must choose either one of the competing policies-the federal labor policy or the state judicial policy-at the expense of the other, two possible alternative solutions which would seek to accommodate these competing policies should at least be considered. One of these proposals would permit disobedience when, and only when, the employees subject to the injunction were in imminent danger of suffering an irreparable loss of position if they continued to obey the injunction. ${ }^{51}$ The other approach would seek to avoid placing the employees in the position of being forced to choose between disobedience of the state injunction and "losing the strike" by securing a review of the question of the jurisdiction of the state court by a federal tribunal before any irreparable harm could ensue to the employees. ${ }^{52}$

The first of these proposed solutions would substitute for the absolute duty to obey a requirement of reasonable compliance: the duty to obey only until further obedience would result in irreparable harm to the employees' position in the labor dispute. This is a compromise which offers to the state courts a measure of obedience. But when the duty to obey begins to conflict with other important interests, the defendant would be free to risk his evaluation of the court's jurisdiction against the court's own opinion and to disobey the state order. This is essentially the proposal espoused in a leading article $e^{53}$ discussing the Mineworkers decision. To justify an act of disobedience, according to this formulation, the employees would have to demonstrate both that further compliance with the temporary injunction would have resulted in irreparable harm, and that prior to disobeying they had exhausted all available means of securing a reversal of the order through legal channels. ${ }^{54}$

One major defect prevents this approach from offering a practical solution to the problem of state labor injunctions: the criteria of this formula are too vague. It would be difficult for thie defendant employees to know when they were faced with what a court would later find to constitute irreparable harm. ${ }^{55}$ In effect, the only safe course of action, from the employees' point of view, would be absolute obedience. From absolute obedience would flow the same dangers

${ }^{51}$ See notes 53-56 infra and accompanying text.

52 See notes 58-65 infra and accompanying text.

${ }^{53}$ Cox, The Void Order and the Duty to Obey, 16 U. CHr. L. REV. 86 (1948).

${ }^{54} I d$. at 113.

${ }^{55}$ Indicative of the many problems inherent in an attempt to measure "irreparable harm" is the difficulty presented by a sympathy strike. In such a situation it is the interest of another union, not the union against which the injunction is directed, which is threatened by continued obedience to the injunction. It would be difficult to discern any direct harm to the enjoined union, much less "irreparable harm." 
to the federal labor program and the interests it seeks to protect as were described above. ${ }^{56}$

The second proposal would involve a procedure for securing prompt review by a federal tribunal of the state court's power to act in the labor dispute, immediately after the issuance of the temporary injunction. If the federal tribunal found that the state injunction impinged upon the preempted area, it would restrain further proceedings in the state court. This solution would require absolute obedience by the employees to the state court injunction. But it would afford a means of securing a review of the state court's claim of jurisdiction before a federal tribunal shortly after the granting of the state injunction. Assuming that this review could be accomplished before the state injunction seriously impaired the employees' position, this suggestion has several advantages. Employees would not be forced to flaunt court orders in order to ascertain and preserve their rights. The federal government would gain an opportunity to acquire jurisdiction and impose its policies in the dispute while those policies could still exert practical influence on the outcome. An orderly response to state labor injunctions could thereby be achieved without sacrificing the effectiveness of the national labor relations program. ${ }^{57}$

Despite these advantages, this proposal probably remains only a theoretical alternative-not a practical possibility-since no procedure currently exists for achieving a sufficiently prompt review before a federal tribunal of the jurisdiction of state courts in labor disputes. The Supreme Court, in Amalgamated Clothing Workers v. Richman Bros. Co. ${ }^{58}$ explicitly held that employees are foreclosed from directly petitioning the federal courts for relief from state labor injunctions. In the same opinion, the Court suggested, however, that the seeking of a state court injunction by an employer in an area preempted by federal law might constitute an unfair labor practice cognizable by the NLRB..$^{59}$ But the NLRB has not followed this suggestion. The Board recently overruled one of its pre-Richman cases and held that an employer's attempt to obtain a state labor

${ }^{36}$ See notes 34-41 supra and accompanying text.

${ }^{57}$ Of course, this proposal is subject to criticisms in even its most ideal form. (1) If the first federal tribunal which hears the case upholds the state court claim of jurisdiction, any later reversal of that initial finding would probably be of little avail. On the other hand, the federal government would at least have had an opportunity to interpose its policies at an early stage of the dispute. In most instances in which federal jurisdiction is proper the initial federal tribunal would probably make a correct determination and take action to enjoin the state order. (2) The states might object to the interference of a federal tribunal in state court proceedings. One answer to this objection is that the federal interest in gaining an early resolution by a federal tribunal of state jurisdiction in labor disputes may outweigh any irritation that this process may cause to state courts.

58348 U.S. 511 (1955).

s9 "[I]t has not yet been determined that, if an employer resorts to a state court in relation to conduct that is obviously taken over by the Taft-Hartley Act ... it may not ... give ground[s] for a finding of an unfair labor practice." Id. at 520 . 
injunction could not constitute an unfair labor practice. ${ }^{60}$ And the reluctance of the NLRB is not the only obstacle to effective review of state labor injunctions as unfair labor practices. The Supreme Court's suggestion extended only to injunctions obviously in excess of state power. ${ }^{\text {of }}$ It would seem that if the state court had a colorable claim of jurisdiction it would not be acting obviously in excess of state power and an employer could not be guilty of an unfair labor practice in seeking such a state injunction.

Even assuming that the NLRB could review any state labor injunction as a potential unfair labor practice, it is doubtful, under the present act, that the review could be completed, and any necessary action taken to suspend the state injunction, before the employees' activity had been effectively curtailed. Without a special priority, not expressly included in the present procedures of the NLRB, ${ }^{62}$ such a case would often not be decided by the Board until after it had become moot. To sanction the tempting expedient of allowing the regional counsel to seek a temporary order suspending the state court injunction pending a decision by the NLRB, ${ }^{63}$ would merely shift the risk of irreparable injury from the employees to the employer should the time required for final disposition by the NLRB be excessive. ${ }^{64}$

Consequently, unless Congress modifies NLRB powers and procedures to cope with this problem, ${ }^{65}$ or unless the Supreme Court reverses its Richman decision and authorizes direct employee petitions for federal action against state labor injunctions, it would appear that this second proposal must likewise be discarded. What is left, then, within the framework of presently existing law, is a choice between furtherance of federal labor policy and promoting the states'

${ }^{60}$ Clyde Taylor Co., 45 L.R.R.M. 1514, 1515 (1960). This decision explicitly overruled W.T. Carter, 90 N.I.R.B. 2020 (1950) which had held that seeking a state injunction was an unfair labor practice if the employer's resort to the state courts was part of a bad faith scheme to defeat union organization.

61 See note 59 supra.

6261 Stat. 146 (1947), as amended, 29 U.S.C.A. $\$ 160(\mathrm{j})(\mathrm{l})(\mathrm{m})$ (Supp. 1959).

${ }^{63} 61$ Stat. 146 (1947), as amended, 29 U.S. C.A. $\$ 60(1)$ (Supp. 1959); 29 U.S.C.A. $\$ \S 102.84$, 102.85 (Supp. 1959).

64 The backlog of cases pending decision before the NLRB would probably be sufficient to render any resolution of the question of jurisdiction by the NLRB too late to be of practical consequence in the dispute. Only by the establishment of a special priority for controversies involving state court injunctions could this time-lag pitfall be avoided.

${ }^{65} \mathrm{This}$ would entail amending the LMRA in at least two respects. First, a provision would have to be inserted granting the NLRB authority to seek injunctions against any state order which it found to be infringing on the federal area, irrespective of whether the state court had a colorable claim of jurisdiction. This could be accomplished either by adding a new section specifically establishing this as a new power of the NLRB, or by explicitly adding it to the list of employer activities which constitute unfair labor practices under the act.

Secondly, the time lag problem would have to be overcome by providing the NLRB with procedures for reaching an early decision on the issue of state court jurisdiction. Special time priorities, similar to those granted to certain classes of cases in sections $10(\mathrm{j})$ and $10(1)$ of the present LMRA, would have to be extended to the state labor injunction problem. Preferably the hearing of cases involving the jurisdiction of state courts should be granted a priority superior to all other classes of cases considered by the NLRB. 
interest in effective judicial administration. Choosing the former would mean application of the traditional equity rule by the Supreme Court; ${ }^{66}$ choosing the latter would allow the states to apply Mineworkers. ${ }^{67}$ The Supreme Court may have made the latter choice in denying certiorari in Aladdin ${ }^{68}$ and Bogle v. Jakes Foundry. ${ }^{69}$ If the decision is yet to be made, it is submitted that the potential effect of the enforcement of state injunctions upon federal labor relations policy is sufficient both to render the decision a matter of federal law and to warrant that the federal courts adopt the traditional equity rule in regard to such injunctions.

${ }^{65}$ See note 3 supra. Although this is the course of action most favorable to the employees, it is not an ideal solution from their point of view either. First, they would be forced to risk incurring substantial fines and imprisonment in following their own evaluation of the state court's power to act. Secondly, disobedience would not be available as a means of neutralizing a state court injunction issued without jurisdiction should the state government elect to enforce its temporary decree through direct police action-such as arresting and confining strikers-rather than through initiating contempt actions in the courts.

${ }^{87}$ See notes 4-6 supra, and accompanying text.

68 361 U.S. 865 (1959).

69362 U.S. 401 (1960).

\section{USE OF STATE STATUTES BY FEDERAI DISTRICT COURTS IN EXTRATERRITORIAL SERVICE OF PROCESS}

In Kappus v. Western Hills Oil, Inc., a federal district court interpreted Rule 4(d)(7) of the Federal Rules of Civil Procedure ${ }^{2}$ as authorizing use of a state statute providing for extraterritorial service of process upon a nonresident defendant. ${ }^{3}$ Rule 4(d)(7) provides that it is "sufficient if the summons and complaint are served ... in the manner prescribed by the law of the state in which service is made for the service of summons [or] other like process upon any such defendant in an action brought in the courts of general jurisdiction of that state." Prior opinions have stated that 4(d)(7) must be interpreted as authoriz-

124 F.R.D. 123 (E.D. Wis. 1959).

2 Congress has delegated the rule making power to the Supreme Court. 28 U.S.C. $\S 2072$ (1958).

${ }^{3}$ There has been considerable discord in the federal courts as to the situations in which extraterritorial service is authorized by the Rules. Compare Farr v. Cia. Intercontinental De Navegacio de Cuba, 243 F.2d 342 (2d Cir. 1957), and Giffin v. Ensign, 234 F.2d 307 (3d Cir. 1956), and Hellriegel v. Sears, Roebuck \& Co., 157 F. Supp. 718 (N.D. Ill. 1957), with Heiser Ready Mix Co. v. Fenton, 265 F.2d 277 (7th Cir. 1959) and Pasternack v. Dalo, 17 F.R.D. 420 (W.D. Pa. 1955), and Johnson v. Scarborough, 88 F. Supp. 523 (S.D. Tex. 1949).

1 "[T] he law of the state in which service is made" might conceivably be read to mean that the law which governs service is that of the state in which the defendant receives notice of the action, rather than the state from which service emanates. Such a construction would have absurd results in that each district court would be empowered to serve nationwide process, conforming only to the state statute providing for intrastate personal service in whatever state the defendant might be found. Although the language of the Rule is inherently ambiguous, the Rule makes sense only if the state law referred to is that of the state in which the district court sits. No court has made a contrary interpretation. 